\title{
STRATEGI PEMBELAJARAN SEJARAH BERBASIS LAGU-LAGU PERJUANGAN DALAM KONTEKS KESADARAN NASIONALISME
}

\author{
Brigida Intan Printina*
}

\begin{abstract}
Abstrak
Di masa-masa kebangkitan nasional lagu-lagu perjuangan menjadi sarana vital dalam membangkitkan kesadaran nasional para pemuda bangsa. Namun, mayoritas pemuda saat ini tidak mampu menunjukkan semangat nasionalismenya karena kurang mengerti akan makna lagu-lagu perjuangan. Maraknya lagu asing semakin menggerus nilai nasionalisme.

Penelitian ini menggunakan kualitatif deskriptif melalui studi pustaka. Penelitian ini dilakukan untuk mengembangkan strategi pembelajaran sejarah agar setiap pemuda dapat membangun diri dan mampu membentuk kesadaran nasionalisme dengan menyanyikan dan menghayati lagu-lagu perjuangan di setiap kesempatan.
\end{abstract}

\section{Kata Kunci : strategi pembelajaran sejarah, lagu perjuangan, nasionalisme}

\section{Pendahuluan}

Tumbuh dan berkembangnya nasionalisme di Indonesia tidak sematamata didasarkan pada persamaanpersamaan primordialistik, akan tetapi sudah bersifat terbuka. Diilhami oleh citacita kebangkitan nasional dari tahun 1908, pada tanggal 28 Oktober 1928 para pemuda Indonesia mengikrarkan Sumpah Pemuda, yaitu satu nusa, satu bangsa, dan satu bahasa. Bahasa Melayu yang diakui sebagai bahasa nasional, merupakan suatu kekalahan bagi bangsa Belanda, sebagai simbol ikrar, teks Sumpah Pemuda serta lagu kebangsaan "Indonesia Raya" menggunakan bahasa Indonesia dan berlakunya musik diatonis. Akhirnya disimpulkan guna menetralisir keanekaragaman para pemuda Indonesia peranan musik nasional tidak lagi berpihak kepada etnis Jawa atau salah satu budaya etnis di Nusantara, melainkan harus bersifat universal seperti dalam kedudukan musik diatonis. (R.M. Soedarsono, 1998 : 39).

Di samping memiliki kemampuan dalam pengajaran, guru juga harus mengembangkan strategi belajar mengajar. Salah satu cara untuk membentuk karakter peserta didik dalam pembelajaran sejarah ialah dengan cara mengumandangkan dan membiasakan kegiatan belajar mengajar dengan lagu-lagu perjuangan yang sarat dengan nilai-nilai positif dan pesan moral di dalamnya. Saat ini sangat sedikit generasi yang dapat menyanyikan lagu perjuangan, bahkan ketika ditanya kebanyakan menjawab tidak tahu. Berbeda dengan kondisi di era tahun 70-an lagu Indonesia Raya diputar sebagai lagu pembuka siaran stasiun TVRI dan lagu Rayuan Pulau Kelapa 
selalu diputar sebagai lagu penutup. Lagulagu perjuangan menjadi berubah situasi karena tidak lagi dikenal dekat oleh para pendengar. Untuk peserta didik di sekolah khsususnya, keberadaan lagu-lagu nasional hanya merupakan bagian dari materi pelajaran yang ada dalam kurikulum dan mungkin saja mereka hanya mendengarkan atau menyaksikan pada saat-saat tertentu, misalnya pada upacara bendera dengan manyanyikan lagu Indonesia Raya. Pengenalan mereka terhadap lagu itu pun belum sampai pada pemakanaan yang sesungguhnya, artinya sifatnya hanya untuk dihapalkan.

Kondisi ini tentu saja harus menjadi perhatian bagi para praktisi pendidikan, khususnya guru sejarah bahwa mengimplementasikan lagu perjuangan pada pembelajaran bukan hanya pada tataran literal dan inferensial, namun sudah pada tahapan apresiasi. Peserta didik tidak hanya dapat mengingat syair, akan tetapi juga dapat memahami syair lagu perjuangan tersebut. Oleh karena itu, perlu adanya wacana atau inovasi dalam mengimplementasikan lagu perjuangan di setiap materi ajar sejarah pada peserta didik.

Lagu-lagu perjuangan adalah lagulagu yang menyerukan sikap nasionalisme bangsa yang semestinya wajib dihapalkan oleh peserta didik. Lagu-lagu perjuangan sebagai salah satu produk atau karya cipta budaya masyarakat Indonesia di bidang musik telah menyatu dengan jiwa masyarakat Indonesia yang memiliki fungsi kompleks dalam aktivitas budaya masyarakat.

Lagu perjuangan Indonesia disebut dengan istilah musik fungsional yang diciptakan untuk tujuan nasional. Fungsi primer lagu-lagu perjuangan Indonesia adalah sebagai sarana upacara, dan acaraacara besar lainnya, namun sejauh ini dapat digunakan sebagai sarana pembelajaran. Fungsi sekunder lagu-lagu perjuangan sebagai media agitasi politik berguna untuk membangkitkan semangat perjuangan melawan penindasan, dan keberadaan jenis lagu-lagu ini di Indonesia pada masa perang kemerdekaan jumlahnya cukup banyak. Dalam pengertian yang luas sebagai perasaan nasional lagu-lagu perjuangan disebut sebagai lagu wajib, diajarkan meski pada tingkat pendidikan dasar, hingga perguruan tinggi dan wajib diketahui seluruh masyarakat Indonesia.

Lagu-lagu Perjuangan adalah karya monumental, beberapa hal yang termasuk dalam kriteria tersebut. Pertama, lagu-lagu perjuangan Indonesia bersifat peringatan hari besar nasional sering dikumandangkan pada momen tertentu. Kedua, fungsinya meningkatkan kewibawaan pencipta dan lingkungannya diidentifikasikan melalui proses yang panjang dari pengakuan pemerintah dan publik, sekaligus penghargaan yang diterima oleh para penciptanya. Ketiga, eksistensi karya seni 
yang bersangkutan telah dibahas melalui opini publik, media massa, buku, seminar dan diskusi ${ }^{1}$.

Lagu-lagu perjuangan dalam rangka Sapta Usaha Tama, Menteri Muda Dep. P dan K. telah mengeluarkan Instruksi No. 1 tanggal 17 April 1960 yang ditujukan kepada seluruh sekolah-sekolah agar mempelajari dan menyanyikan lagu-lagu wajib nasional yang berjumlah tujuh buah. Setelah adanya perkembangan di Indonesia, maka jumlah lagu-lagu wajib nasional berjumlah menjadi 16 buah, kemudian berkembang lagi saat ini menjadi 45 lagulagu perjuangan.

Lagu-lagu perjuangan dari 45 buah tersebut dapat di klasifikasikan menjadi 3 jenis yaitu lagu-lagu perjuangan bersifat mars, lagu-lagu perjuangan bersifat Himne, dan lagu-lagu perjuangan bersifat percintaan (Romans). Keberadaan dan penciptaan lagu-lagu perjuangan dapat pula diklasifikasikan menjadi 3 periode. Pertama, lagu-lagu perjuangan yang di cipatakan pada masa pra-kemerdekaan tahun 1928 contohnya lagu 'Indonesia Raya' (W.R.Supratman) Kedua, lagu-lagu yang diciptakan masa Revolusi Indonesia 19451949, contohnya lagu 'Maju Tak Gentar (Cornel Simanjuntak). Ketiga, lagu-lagu perjuangan yang diciptakan pada masa

\footnotetext{
1 Supriatun. Pedoman Nasah Porto Folio Karya Seni Monumental Pertunjukan.
} Jakarta:Depdiknas. 2008. hal. 9 pasca kemerdekaan, contohnya lagu Andika Bhayangkari (Amir Pasaribu).

Fungsi lagu-lagu perjuangan sebagai kegiatan upacara dapat di jumpai pada HUT RI 17 Agustus, antara lain menjadi 3 macam kegiatan. Pertama berfungsi sebagai Defile penghormatan upacara seperti lagu kebangsaaan 'Indonesia Raya', lagu 'Andhika Bhayangkari', lagu 'Mengheningkan cipta'. Kedua, berfungsi sebagai Aubade, kegiatan paduan suara dan orkes simponi menyanyikan lagu-lagu perjuangan bergema setelah upacara pengibaran sang saka merah putih, dan juga menjelang upacara penurunan bendera merah putih. Seperti menyanyikan lagu 'Hari Merdeka' lagu 'berkibarlah Benderaku' lagu 'Dari Sabang sampai Mereuke' lagu 'Syukur' dan lain sebagainya.

Ketiga, berfungsi sebagai parade, yaitu jenis iringan musik mars lagu-lagu perjuangan dalam kegiatan mengawali dan menghakhiri pawai barisan dengan derap langkah semangat perjuangan memasuki atau keluar lapangan upacara HUT RI 17 Agustus di Istana Presiden gedung Agung Yogyakarta. Dalam acara karnaval lagu-lagu perjuangan sering dipakai pada reportoar Drumband atau kelompok Marching Band yang sering mengumandangkan lagu Mars 'Maju tak gentar' atau Mars 'Bambu Runcing' dan lain sebagainya.

Melalui lagu perjuangan para peserta didik dapat mempelajari banyak hal. Di sekolah guru dapat menggunakan lagu 
untuk menerangkan tentang cinta tanah air, lingkungan, kesetiakawanan sosial, semangat kebangsaan dan lain-lain. Lagu perjuangan tidak hanya dikenalkan sebagai hiburan, akan tetapi juga memanfaatkannya untuk mengambil pesan dan makna positif tentang kehidupan berkebangsaan dan cinta tanah air.

Pengamatan interpretasi lagu dengan revitalisasi sejarah perjuangan muncul ketika kita masuk museum Venderburg Yogyakarta melihat diorama perjuangan lewat audio visual dan sinopsis peristiwa yang dibacakan dengan iringan musik lagu perjuangan. Atau pada saat kita mengikuti detik-detik proklamasi kenerdekaan di Istana Negara Jakarta dan di Istana Presiden gedung Agung Yogyakarta, menyebabkan interpretasi rasa nasionalisme kita makin kuat saat itu. Selain itu memahami sejarah prakemerdekaan saat menyanyikan lagu 'Indoesia Raya' lagu ini juga menggambarkan sumpah pemuda 28 Oktober 1928.2

Jadi untuk memahami lagu perjuangan sebaiknya dibarengi dengan kemampuan guru untuk menyampaikannya dalam pembelajaran sehingga pengetahuan anak tentang sejarah perjuangan Indonesia mampu dipahami secara utuh, sehingga identitas lagu-lagu perjuangan terlihat jelas kedudukannya. Guru dalam menerapkan

\footnotetext{
${ }^{2}$ Sutrisno Kutojo dan Mardanas Safwan. Pahlawan Nasional W.R. Supratman. Jakarta: Mutiara. 1978. hal. 70
}

strategi pembelajaran sejarah sudah semestinya mengedepankan lagu-lagu perjuangan agar muncul kesadaran nasionalisme dalam diri setiap pemuda bangsa. Penelitian ini diarahkan untuk mengembangkan strategi belajar sejarah di setiap lembaga pendidikan agar semakin dinamis dan penuh makna. Diharapkan melalui strategi ini peserta didik tidak lagi mengutamakan lagu-lagu asing yang tidak bermutu atau sebagai sarana hiburan, namun menghayati lagu-lagu perjuangan sebagai pedoman hidup. Dengan demikian strategi belajar sejarah ini dapat menjadi sarana bagi pembelajaran sejarah untuk menumbuhkan kesadaran nasionalisme pemuda bangsa.

\section{Tinjauan Pustaka}

Penelitian ini dilakukan dengan menggunakan studi pustaka. Buku-buku karangan Wisnu Mintargo baik menjadi acuan karena mengulas beberapa lagu-lagu perjuangan dan ditulis dalam buku terbitan Ombak tahun 2001 berjudul Musik Revolusi Indonesia. Sebelumnya Wisnu Mintargo juga menulis dalam tesisnya berjudul Fungsi Lagu Perjuangan Indonesia Dalam Konteks Kemerdekaan Tahun 1945-1949 dan Lagu Perjuangan Sebagai Media Propaganda dalam Jurnal Palanta Seni Budaya No. 6 tahun 2000. Semua karangan Wisnu Mintargo secara konsisten menunjukkan proses perkembangan lagu-lagu perjuangan pada masanya. Sumber lainnya antara lain, pertama, buku karangan Sri Martono yang 
berjudul Kehidupan Seni Suara Tahun 19451952 yang diterbitkan oleh Kementerian Penerangan Republik Indonesia tahun 1953. Kedua, buku karangan Diater Mack dengan judul Sejarah Musik Jilid 4 oleh penerbit Pusat Musik Liturgi Yogyakarta tahun 1995. Ketiga, lagu-lagu perjuangan Indonesia juga tertuang dalam buku internasional karangan Romain Rolland berjudul The International Library of Music for Home and Music Literatur 2 yang diterbitkan oleh University Society New York tahun 1962. Secara implisit beberapa karangan sekunder juga menggambarkan proses berkembangnya lagu-lagu perjuangan selama masa kolonial hingga kemerdekaan.

Untuk sumber strategi pembelajaran sejarah di sekolah maka digunakan beberapa acuan buku yang dapat disesuaikan dengan kurikulum ajar. Buku karangan Merill Harmin dan Melanie Toth memberi banyak gambaran tentang berbagai strategi pengajaran termasuk menggunakan lagu-lagu sebagai media yang mempengaruhi intelegensi anak. Buku ini berjudul Pembelajaran Aktif yang Menginspirasi; Buku Pegangan Lengkap untuk Guru Masa Kini. Buku ini telah diterjemahkan Bethari Anissa oleh Penerbit Indeks Permata Puri Media Jakarta tahun 2012. Buku lain yang digunakan ialah karangan Miftahul Huda dengan judul Model-Model Pengajaran dan Pembelajaran: Isu-Isu Metodis dan Paradigmatis oleh
Penerbit Pustaka Pelajar Yogyakarta tahun 2013.

\section{Metode Penelitian}

Jenis penelitian ini ialah penelitian deskriptif karena penelitian ini memiliki tujuan untuk memperoleh jawaban yang terkait dengan pendapat, tanggapan atau persepsi seseorang sehingga pembahasannya harus secara kualitatif atau menggunakan uraian kata-kata. "Penelitian deskriptif mencoba mencari deskripsi yang tepat dan cukup dari semua aktivitas, objek, proses, dan manusia." (Sulistyo-Basuki, 2010:110).

Penelitian deskriptif mengenal berbagai bentuk yang dapat dikategorikan seperti survey, studi kasus, kajian, kausalkomparatif, kajian kolerasi, dan sebagainya. Setiap bentuk peneltian deksriptif mempunyai fungsi dan tujuan yang berbeda, sedangkan penelitian ini termasuk dalam kategori "Studi Kasus".

Studi Kasus merupakan kajian yang mendalam tentang peristiwa, lingkungan, dan situasi tertentu yang memungkinkan mengungkap atau memahami suatu hal. Penulis menggunakan bentuk penelitian studi kasus karena mengangkat fenomena yang terjadi terhadap kesadaran pembelajaran sejarah saat ini. Penelitian ini dilakukan melalui studi pustaka dari sumber-sumber yang terdapat di perpustakaan, book shop, video-video pembelajaran di berbagai daerah. 
Strategi pembelajaran sejarah berbasis lagu-lagu perjuangan dalam konteks kesadaran Nasionalisme akan dikaji menggunakan metode kualitatif deskriptif. Data yang dikumpulkan berupa kumpulan perkembangan lagu-lagu perjuangan dari masa ke masa di sesuaikan dengan pengamatan peneliti. Peneliti lebih menekankan catatan dengan deskripsi kalimat yang rinci, lengkap, dan mendalam. (H.B, Sutopo, 2006:40). Laporan penelitian akan menunjukkan data-data dari berbagai sumber yang hasilnya akan digunakan untuk menjawab permasalahan dalam penelitian ini.

\section{Hasil Dan Pembahasan}

\section{Strategi Belajar Sejarah Berbasis Lagu-} Lagu Perjuangan

\section{Strategi Musik Latar}

Strategi ini bertujuan untuk mengarahkan siswa dan memulai kelas dengan atmosfer kelas yang positif. Para siswa dapat memainkan musik perjuangan agar mereka mampu memasuki ruangan dengan penuh gairah dan belajar mandiri.

Pada saat guru menghendekai siswa agar melakukan tugas mandiri ada baiknya memulai musik latar dengan menyanyikan lagu perjuangan. Beberapa siswa yang berbakat di bidang music dapat membawa alat music saat pelajaran sejarah berlangsung dan mereka dapat memainkan musik. Guru dapat juga meminta sisswa untuk membandingkan pengalaman mereka saat bekerja dengan tanpa musik.
Memainkan musik dengan lagu-lagu perjuangan pada mata pelajaran sejarah dapat memberikan hasil yang di luar dugaan. Apalagi saat mereka harus mengerjakan tugas kelompok, dengan tema Revolusi Indonesia. Apabila bersamaan dengan iringan lagu maka jiwa dan pemikiran mereka menjadi satu karena semangat itu berkobar dalam hati para siswa. ${ }^{3}$

\section{Strategi Mengekspresikan}

\section{Semangat Revolusi}

Sebelum pelajaran dimulai guru dapat memutar musik seperti instrumental lagu "Tanah Airku". Instrumen lagu ini menjadi pembangkit motivasi siswa. Mereka semakin bergairah karena di awal pembelajaran sejarah diperdengarkan lagu bermakna cinta terhadap negeri Indonesia.

Penelitian-penelitian membuktikan bahwa music yang memperdengarkan lagulagu perjuangan memberi banyak manfaat seperti merangsang pikiran, memperbaiki konsenterasi dan ingatan, membangun kecerdesan emosional. Musik juga dapat menyeimbangkan perkembangan aspek intelektual dan emosional. ${ }^{4}$

Langkah-langkah pembelajaran mengekspresikan semangat Revolusi lewat Lagu Perjuangan:

\footnotetext{
3 Merril Harmin, Pembelajaran Aktif yang Menginspirasi, Jakarta: Indeks. 2012, hlm 127

4 Nurita Putranti, Musik dalam Pembelajaran
} 
1) Guru memberikan tujuan pembelajaran dan pengantar materi Pergerakan Nasional

2) Para siswa dibagi dalam beberapa kelompok dan setiap kelompok ada beberapa anggota yang mampu bernyanyi dan memainkan music

3) Para siswa diberi topik dan berdiskusi lagu perjuangan apa yang tepat untuk menunjukkan semangat nasionalisme

4) Setelah selesai berdiskusi, kelompok mempresentasikan materi sambil menunjukkan semangat nasionalisme dengan bernyanyi

5) Kelompok lainnya memberikan penilaian

Dengan strategi ini diharapkan para siswa sadar dan menjiwai materi yang didapat dan mampu mengimplementasikan sikap nasionalisme di kehidupan seharihari.

\section{Strategi Talking Stick}

Beberapa siswa terkadang bosan dengan penjelasan materi yang diberikan guru apabila tidak dibawakan dengan ekspresif. Maka guru dapat menggunakan strategi ini untuk mencairkan suasana, khususnya pada saat mata pelajaran sejarah ditempatkan di akhir pembelajaran.

Sugihharto (2009) mengemukakan bahwa model pembelajaran talking stick termasuk dalam pembelajaran kooperatif karena memiliki ciri-ciri yang sesuai dengan pembelajaran kooperatif yaitu: (1) Siswa bekerja dalam kelompok secara kooperatif untuk menuntaskan materi belajarnya, (2) Kelompok dibentuk dari siswa yang memiliki kemampuan tinggi, sedang dan rendah, (3) Anggota kelompok berasal dari ras, budaya, suku, jenis kelamin yang berbeda, serta (4) Penghargaan lebih berorientasi kelompok ketimbang individu.

Metode Talking Stick adalah proses pembelajaran dengan bantuan tongkat yang berfungsi sebagai alat untuk menentukan siswa yang akan menjawab pertanyaan. Pembelajaran dengan metode Talking Stick bertujuan untuk mendorong siswa agar berani mengemukakan pendapat. Metode pembelajaran Talking Stick dalam proses belajar mengajar di kelas berorientasi pada terciptanya kondisi belajar melalui permainan tongkat yang diberikan dari satu siswa kepada siswa yang lainnya. Tongkat digulirkan dengan diiringi lagu.

Pada saat lagu berhenti maka siswa yang sedang memegang tongkat itulah yang memperoleh kesempatan untuk menjawab pertanyaan tersebut. Metode pembelajaran Talking Stick dilakukan hingga sebagian besar siswa berkesempatan mendapat giliran menjawab pertanyaan yang diajukan guru. Penggunaan metode ini menuntut siswa untuk berpartisipasi aktif selama pembelajaran, siswa harus selalu siap menjawab pertanyaan dari guru ketika stick yang digulirkan jatuh kepadanya (Rahayu, 2013).

Metode Talking Stick sebaiknya menggunakan iringan music atau 
menyanyikan lagu ketika stick bergulir dari satu siswa ke siswa lainnya dalam menentukan siswa yang menjawab pertanyaan didalam tongkat bertujuan siswa menjadi lebih semangat, termotivasi serta proses belajar mengajar menjadi lebih menyenangkan (Suprijono, 2009).

Widodo (2009), menjelaskan bahwa sintaks atau langkah-langkah pembelajaran dengan menggunakan model pembelajaran talking stick, yaitu sebagai berikut:

a. Guru menjelaskan tujuan pembelajaran/KD.

b. Guru menyampaikan materi pokok yang akan dipelajari, kemudian memberikan kesempatan kepada siswa untuk membaca dan mempelajari materi lebih lanjut.

c. Setelah siswa selesai membaca materi/buku pelajaran dan mempelajarinya, siswa menutup bukunya dan mepersiapkan diri menjawab pertanyaan guru.

d. Guru menyiapkan sebuah tongkat.

e. Guru menghendaki bahwa semua siswa menyanyikan lagu perjuangan sambil bernyanyi dan akan berhenti sesuai intruksi guru.

f. Ketika lagu berhenti guru memberikan pertanyaan pada siswa yang memegang stick tersebut.

g. Demikian seterusnya sampai sebagian besar siswa mendapat bagian untuk menjawab setiap pertanyaan dari guru. h. Guru dan siswa menyimpulkan dan melakukan kegiatan reflektif terkait pembelajaran.

\section{Strategi menggunakan metode Kurun Waktu (Time Line)}

Dalam sejarah konsep waktu sangat penting untuk mengetahui peristiwa masa lalu dan perkembangannya hingga saat ini. Secara umum guru sejarah mengimplementasikan pembelajaran sejarah yang menimbulkan kesan hafalan dan membuat bosan para peserta didik, maka perlu motivasi-motivasi yang dapat digunakan dalam pelaksanaan kegiatan pengajaran sejarah dengan menggunakan metode kurun waktu sebagai berikut.

a. Salah satu materi yang dapat digunakan dan disesuaikan dengan lagu-lagu perjuangan ialah materi Periodesasi dan Kronologi Sejarah kelas X SMA

b. Guru mempersiapkan perencanaan yang meliputi lagu-lagu perjuangan, beserta medianya.

c. Guru mampu menganalisis peristiwa tentang latar belakang lahirnya lagu perjuangan tersebut

d. Guru membagi kelas menjadi beberapa kelompok dan setiap kelompok diberi tugas untuk mencari materi tentang lagu perjuangan yang didapatkan

e. Siswa dalam kelompok mempresentasikan hasil proyeknya dan memberikan informasi kepada teman yang lain. 
f. Guru memfasilitasi diskusi dan bersama-sama siswa menarik kesimpulan

\section{Strategi tebak lagu}

Sebagai seorang guru sejarah, metode mengajar sejarah yag monoton tentu sangat tidak direkomendasikan.Metode mengajar sejarah dengan menggunakan lagu-lagu perjuangan sudah sepantasnya dicoba dalam proses belajar mengajar sejarah.

Berikut merupakan langkah dari strategi tebak lagu:

1) Siswa mulai mendengar beberapa lagu perjuangan dan guru mengajak para siswa untuk bernyanyi. Dengan menyanyikan lagu perjuangan siswa akan merasa senang, karena mereka dapat mengekspresikan diri

2) Setelah menikmati lagu tersbut, maka guru dapat menghilangkan beberapa lirik lagu, sehingga para siswa dapat menebak lirik lagu yang hilang tersebut

3) Selanjutny siswa mempersiapkan diri untuk maju kedepan dan menyanyikan lagu tersebut

Cara ini dapat dilakukan antar siswa dengan siswa dalam kelompok. Siswa yang dapat menebak lirik lagu terlebih dahulu dibanding teman lain maka akan mendapatkan kesempatan untuk membuat soal dan berhak menghilangkan beberapa lirik lagu untuk ditebak.
Lagu-Lagu Perjuangan dan Fungsinya Pembelajaran Sejarah

\section{Api Kemerdekaan}

a. Lagu Api Kemerdekaan

Lagu Api Kemerdekaan adalah sebuah lagu perjuangan yang sarat dengan semangat yang menyala bagai api yang berkobar untuk membela negara. Melodi lagu ini diciptakan oleh Djoko Lelono dan syairnya ditulis oleh Martono. Berikut merupakan partitur dan syair lagu Api Kemerdekaan.

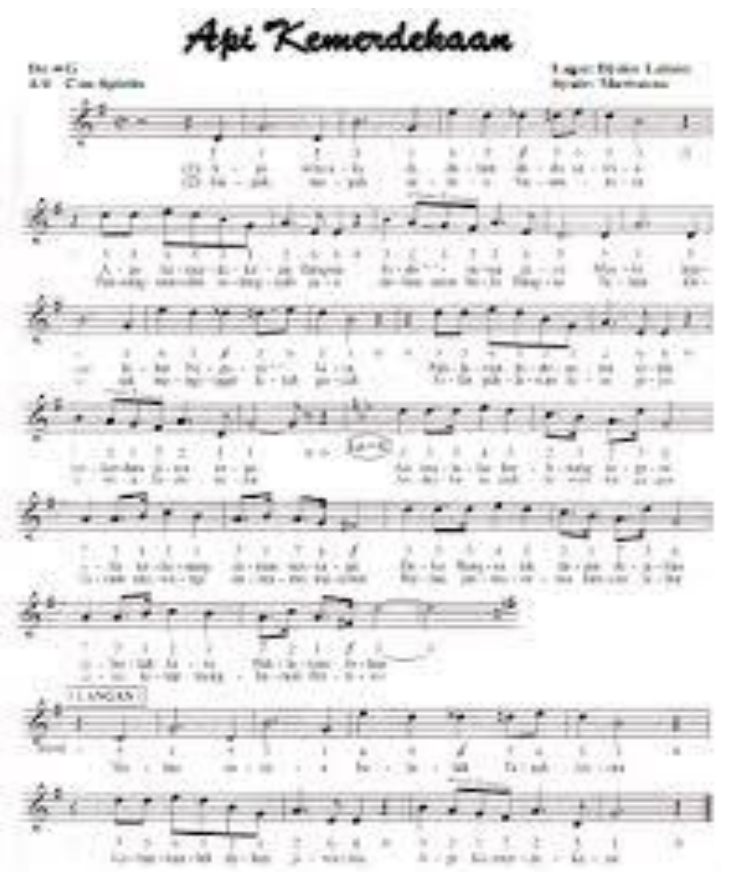

Gambar 4.1: Partitur Lagu Kemerdekaan Sumber:httpswww.google.co.idimgres.jpg

\section{b. Fungsinya dalam Pembelajaran}

\section{Sejarah}

Lagu Api Kemerdekaan bertema perjuangan ini bercerita tentang semangat pahlawan Indonesia yang rela berkorban demi jiwa raga dan membela kejayaan 
negara. Sedangkan semangat patriot bangsa berkobar bagaikan api yang menyala. Hal ini dilakukan demi kemerdekaan, maju terus pantang mundur, dan rela mati demi harumnya ibu pertiwi.

Lagu-lagu di atas dapat menjadi contoh dalam upaya pembentukan karakter budaya bangsa melalui pembelajaran musik. Masih banyak lagu-lagu nasional yang sarat dengan pesan-pesan moral yang dapat dijadikan semangat juang bagi generasi penerus bangsa dalam membela tanah air tercinta.

\section{Kebangsaan Indonesia Raya}

\section{a. Lagu Kebangsaan Indonesia Raya}

Wage Rudolf Supratman 1903-1938 merupakan pencipta lagu 'Kebangsaan Indonesia Raya' setelah tergugah hatinya membaca surat kabar Fajar Asia. Artikel itu menyatakan 'mana ada komponis bangsa kita yang mampu menciptakan lagu 'Kebangsaan Indonesia' yang dapat menggugah semangat rakyat. Kemudian, ia berhasil menciptakan lagu Indonesia Raya sesudah berkonsultasi dengan Ketua Himpunan pelajar Indonesia A. Sigit, Sugondo Djoyo Puspito dan Monomutu.

Setelah mendapat izin Ketua kongres pemuda pada tanggal 28 Oktober 1928 berkumandang pertama kalinya karya monumental lagu 'Kebangsaan Indonesia Raya' di gedung Indonesische Club jalan Kramat 106 Jakarta, setelah ikrar sumpah pemuda. Betapa hebatnya lagu itu berkumandang hingga peserta kongres pemuda memberi sambutan luar biasa. Supratman menerima ucapan selamat dan pelukan dari rekan-rekannya.

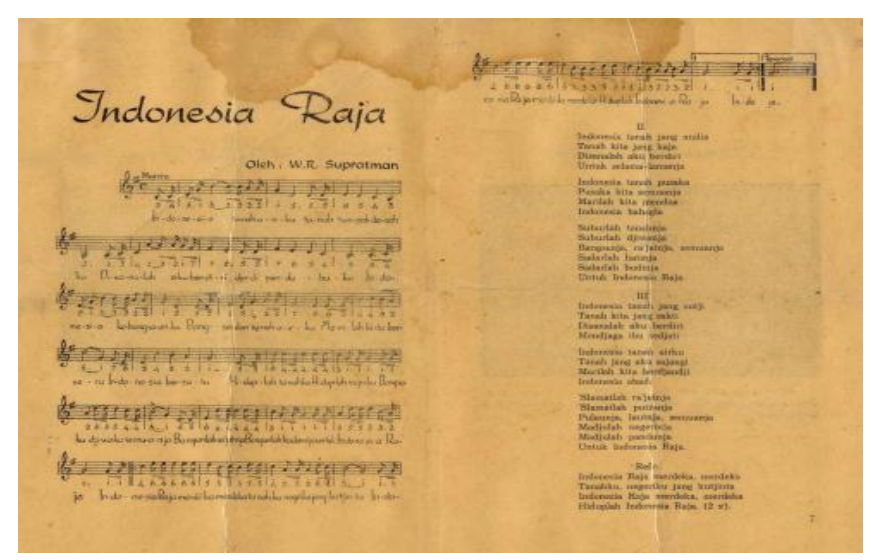

\section{Gambar 4.2: Naskah Asli Lagu Indonesia Raya. Sumber: sumintar.com}

Sebagai karya monumental lambang negara pada tanggal 17 Agustus 1945 setelah pembacaan teks proklamasi oleh Sukarno maka, lagu "Kebangsaan Indonesia Raya" berkumandang mengiringi Sang Saka Merah Putih sebagai hari kemerdekaan RI di Pegangsaan Timur Jakarta. Atas jasa-jasanya menciptakan lagu 'Kebangsaan Indonesia Raya' pada tanggal 28 Oktober tahun 1953 almarhum W.R. Supratman menerima anugerah penghargaan Bintang Maha Putera Kelas III dari Pemerintah RI. Kemudian guna mengenang hasil perjuangannya menciptakan lagu 'Kebangsaan Indonesia Raya' Hari kelahiran W.R. Supratman tanggal 9 Maret oleh pemerintah RI diperingati sebagai hari Musik Nasional. 


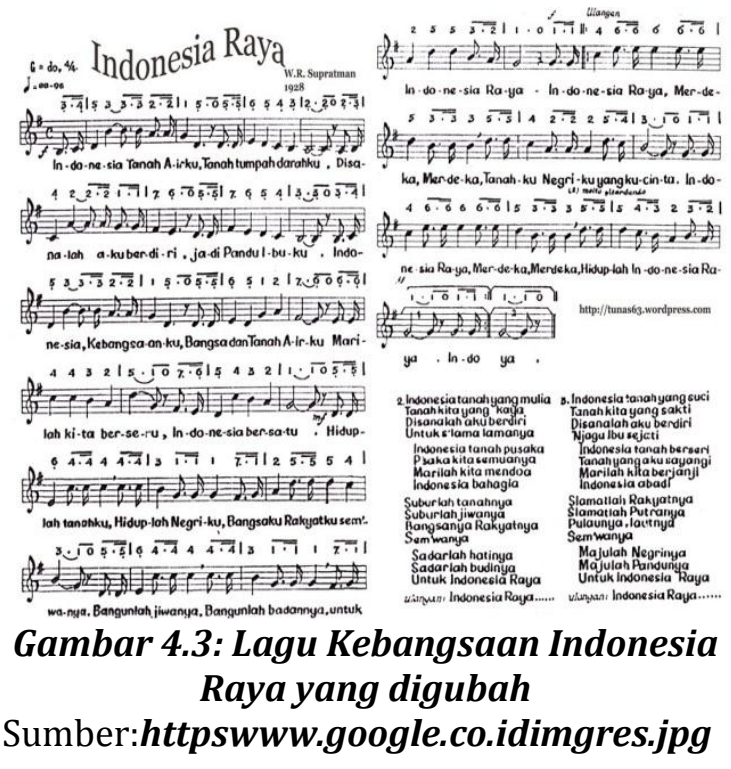

\section{b. Fungsi dalam Pembelajaran Sejarah}

Wisnu Mintargo dalam jurnalnya berjudul Kontinuitas Dan Perubahan Makna Lagu Kebangsaan Indonesia Raya menyatakan ada dua fungsi besar Lagu Indonesia Raya untuk Pembelajaran Sejarah antara lain: ${ }^{5}$

1) Untuk mempersatukan para pemuda berlatar belakang berbagai etnis disebut sebagai perintis kemerdekaan. Pengakuan bahasa untuk persatuan kibatnya kedudukan bahasa nasional menjadi alat komunikasi terpenting dalam berdiplomasi melawan penjajah termasuk teks syair lagu yang terkandung di dalamnya. Bahasa Indonesia sebagai alat komunikasi merupakan pemersatu berbagai etnis yang berbeda-beda merupakan

\footnotetext{
5 Wisnu Mintargo dalam jurnalnya berjudul Kontinuitas Dan Perubahan Makna Lagu Kebangsaan Indonesia Raya, Vol 2, No. 3, Desember 2012. Jurnal Kawistara, Pascasarjana UGM
}

kekalahan bagi bahasa Belanda yang diberlakukan sebagai bahasa pengantar sejak kongres pemuda pertama tahun 1926.

2) Fungsi lagu 'Indonesia' diakui sebagai jati diri bangsa menjadi perdebatan yang hangat di kalangan kaum intelektual pribumi. Polemik kebudayaan yang terjadi sekitar tahun 1930-an antara kelompok yang berpikiran nasionalis tradisional dan kelompok ultranasionalis merupakan fakta yang penting guna digarisbawahi. Polemik menunjukan komitmen kaum intelektual pribumi terhadap masa depan bangsa Indonesia. Kelompok nasionalis tradisional dengan tokohnya Ki Hadjar Dewantara dan Ali Boediardjo menginginkan jati diri bangsa Indonesia dibangun di atas nasionalisme yang tetap berakar pada budaya tradisi yang telah diwariskan oleh para leluhur bangsa. Sebaliknya kelompok ultranasionalis yang dipelopori oleh Sutan Takdir Alisjahbana dan Armijn Pane menghendaki sebuah wacana Indonesia baru yang dibangun di atas reruntuhan budaya lokal. Pemikiran tentang Jati diri bangsa Indonesia di masa depan hendaknya merupakan sebuah diskontinunitas sejarah, dengan mengubur dalam-dalam Chuvinisme etnisitas beserta simbol-simbol budaya lokalnya. 


\section{Bagimu Neg'ri \\ a. Lagu Bagimu Neg'ri}

Lagu 'Bagimu Neg'ri' diciptakan oleh Kusbini (1910-1991) sebagai lambang simbolis penandatanganan sumpah jabatan Kepala negara dan para pejabat berbakti dan mengabdi kepada negara RI. Lagu ini diciptakan atas permintaan Sukarno untuk mengimbangi lagu-lagu propaganda Jepang yang marak saat itu. Kusbini bekerja sebagai pemain biola dan penyiar taman kanakkanak bersama Ibu Sud di Radio Houso Kanri Kyoku. Menurut Ki Suratman tahun 1943-1944 pemerintah Jepang melarang mengumandangkan lagu kebangsaan 'Indonesia Raya' maka lagu 'Bagimu Neg'ri diperdengarkan sebagai pengganti sementara lagu kebangsaan 'Indonesia Raya'. Lagu ini memiliki peranannya dimasa revolusi Indonesia tahun 1945. Atas jasajasanya dibidang musik Kusbini memperoleh penghargaan piagam Anugerah Seni dari Pemerintah RI.

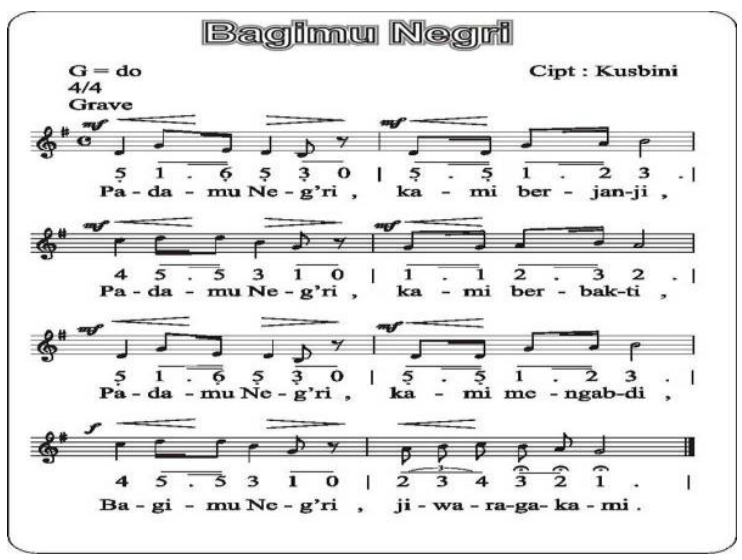

Gambar 4.4: Partitur Lagu Padamu
Neg'ri.
Sumber: httpswww.google.co.idimgres

\section{b. Fungsi dalam Pembelajaran Sejarah}

Lagu Bagimu Neg'ri dimaksudkan adalah Negara Republik Indonesia yang disingkat dengan kata sandi Neg'ri, agar tidak diketahui pemerintah Jepang. Makna lagu 'Bagimu Neg'ri' menurut Kharis Suhud adalah sumpah bakti dan curahan hati seorang nasionalis kepada bangsa dan negara, serta kepada Tuhan Yang Maha Esa untuk mengabdi, berkorban tanpa pamrih demi jiwa raga. ${ }^{6}$

Pada masa pendudukan Jepang Kusbini bekerja pada Organisasi Pusat Kebudayaan (Keimin Buinka Shidoso), mencoba mengungkapkan jiwa patriotisme secara halus melalui lagu ini. Lagu 'Bagimu Neg'ri' bagi penciptanya memiliki kesan tersendiri, ia tercipta ketika Kusbini bekerja di radio Hoso Kanri Kyoku, memimpin orkes bersama Ismail Marzuki dan M. Sagi. Selain bertugas sebagai pimpinan siaran radio taman kanak-kanak bersama ibu Sud, mereka adalah anggota Badan Pusat Kesenian Indonesia yang dibentuk pada tahun 1942.

Ide mengenai pemberian nama Republik dalam lagunya dalam satu bait hakekatnya didapat melalui inspirasi yang dicetuskan Tan Malaka pada saat pengasingan di luar negeri mendirikan partai Republik Indonesia, setelah pemberontakan komunis gagal ditahun

\footnotetext{
6 Jurnal ISI Yogyakarta juli 2003. Perjalanan Sejarah Lagu-Lagu Perjuangan Indonesia Dalam Konteks Persatuan Bangsa
} 
1926. Brosur berjudul Naar Republiek Indonesia (1936) dicetak di Tokyo kemudian diselundupkan dari negara Bangkok ke Indonesia. Isu mengenai nama Negara Republik Indonesia akan berbentuk Republik sebenarnya sudah ada sejak lama didalam konsep pemikiran para pemimpin pergerakan.

Sejak tahun 1935 sebelum perang dunia II selain Tan Malaka, Soekarno dan Mohammad Hatta sudah membahas tentang ini dalam buku-buku tulisan mereka. Kemudian dalam perkembangan berikutnya ide mengenai pemberian nama Negara Republik Indonesia muncul bersamaan, diperkuat lagi hubungan dekat Kusbini dengan orang-orang pergerakan politik berhaluan kanan maupun kiri di kota Surabaya yang berminat belajar musik keroncong padanya, dan dari pembicaraan mereka itulah Kusbini mendengar nama Republik.

Lagu 'Bagimu Negri' pada masa pendudukan Jepang dianggap sebagai lagu perjuangan bersifat terselubung dalam konteks gerakan moral bangsa yang diungkap secara halus dan hati-hati. Pada masa ini lagu 'Bagimu Negri' digunakan di berbagai kesempatan khususnya setiap peringatan hari Sumpah Pemuda 28 Oktober.

\section{Maju Tak Gentar}

a. Lagu Maju Tak Gentar

Pada masa Perang Kemerdekaan, propaganda mengalami perubahan fungsi yaitu penerangan. Menurut Dr. H. Roeslan Abdulgani, Peraturan Pemerintah no. 34/ 1958, perjuangan kemerdekaan masa penjajahan Belanda disebut istilah propaganda bagi salah satu struktur organisasinya. Organisasi ini bertuhas di bidang persuasi guna menangkal propaganda Belanda yang selalu memutarbalikan fakta. Berdasarkan keputusan Dewan Pertahanan Keamanan, propaganda berfungsi bagi penyuluhan masyarakat dalam memberi keterangan dan penerangan positif. Salah satunya mempergunakan komponen lagu-lagu yang dapat membangun semangat rakyat untuk berjuang. ${ }^{7}$

Lagu 'Maju Tak Gentar' pada mulanya adalah lagu propaganda Asia Timur Raya hasil propaganda pemerintah Jepang dan Indonesia berjudul 'Maju Puteraputeri Indonesia' ciptaan Cornel Simanjuntak tahun 1944. Pada tahun 1945 oleh penciptanya diubah menjadi lagu 'Maju Tak Gentar' karena pengalamannya sebagai pejuang, dan baru setelah proklamasi kemerdekaan, lagu ini memperoleh fungsi yang sebenarnya. Lagu 'Maju Tak Gentar' dimaksudkan untuk memotivasi rakyat guna membangkitkan semangat persatuan membela tanah air, yang secara realitas sering ditampilkan potret pertempuran melawan Inggris dan Belanda yang selama

\footnotetext{
7 Sastropoetro. R.A. Santoso. Propaganda Salah satu Bentuk Komunikasi Massa. Bandung: Alumni, 1983. Hlm 13
} 
sekali tidak rasional. Dalam pertempuran itu tampak senapan bekas peninggalan penjajah, bambu runcing, keris, rencong, pedang, clurit melawan senapan otomatis dan meriam. Dengan strategi perlengkapan seadanya ditambah lagi dengan perlawanan yang tidak berimbang, namun pada kenyataannya rakyat Indonesia tidak gentar menghadapinya, seirama dengan semangat lagu 'Maju Tak Gentar'.

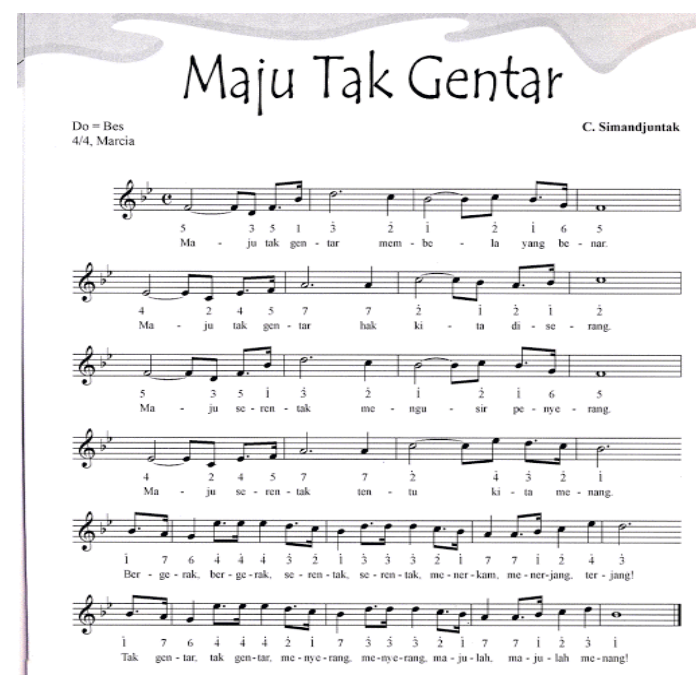

Gambar 4.5: Partitur Lagu Maju Tak Gentar Sumber:

https://www.google.co.id/partiturlagum ajutakgentar

\section{b. Fungsi dalam Pembelajaran Sejarah}

Lagu ini dimaksudkan untuk memotivasi rakyat perang semesta guna membangkitkan semangat membela tanah air, yang secara realitas sering ditampilkan potret pertempuran melawan sekutu dan Belanda yang tidak seimbang. Menurut Franz Seda dan Alex Rumambi lagu ini menjadi terkenal di front Tentara Pelajar Yogyakarta yang mampu membakar semanagat pejuang di medan pertempuran.
Lagu 'Maju tak Gentar' menggambarkan keberanian rakyat dengan perlengkapan seadanya melawan Belandayang bersenjatakan lengkap dan modern, tapi dengan jiwa semangat lagu ini mampu membangkitkan pejuang digaris depan.Atas jasa-jasanya pada pemerintah RI tahun 1961 menerima kehormatan piagam Satya lencana Kebudayaan, setingkat bintang Gerilya. ${ }^{8}$

\section{Hallo-Hallo Bandung \\ a. Lagu Hallo-Hallo Bandung}

Lagu 'Hallo-hallo Bandung' diciptakan oleh Ismail Marzuki pada tahun 1945 berbicara dalam konteks keindahan kota parahyangan Bandung sebelum terjadi peristiwa apapun. Sesuatu hal yang mengejutkan kita semua menjadi menarik perhatian, karena sifat romantis yang dimiliki Ismail Marzuki pada tahun 1945 tiba-tiba berubah sikap menjadi seorang revolusioner dalam membangkitkan semangat perlawanan terhadap sekutu dalam peristiwa Bandung lautan api tangga 24 Maret 1946.

\footnotetext{
${ }^{8}$ Wisnu Mintargo. "Perjalanan Sejarah Lagu-lagu Perjuangan Indonesia dalam Konteks Persatuan Bangsa", dalam Jurnal Seni Pengetahuan dan Penciptaan Seni. Volume IX. No. 04-Juli, 2003. ISI Yogyakarta, hlm. 371.
} 


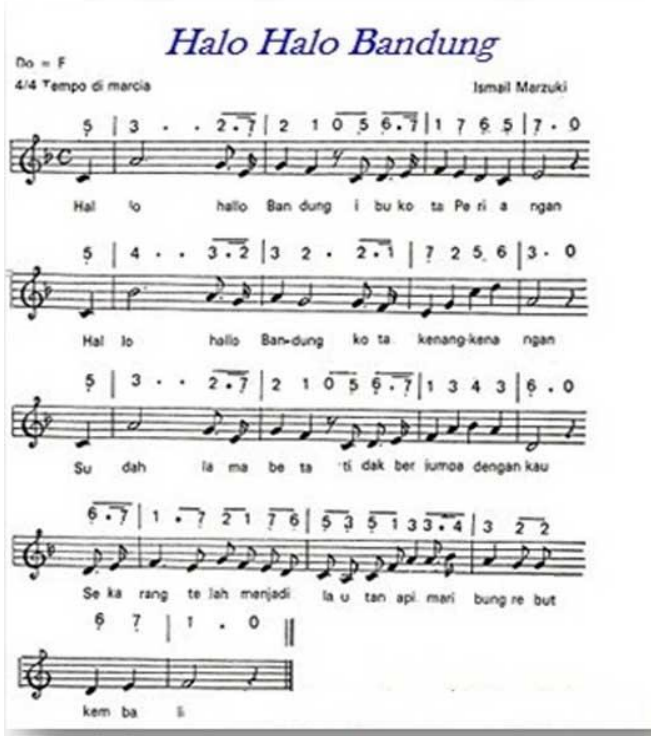

Gambar 4.6: Partitur Lagu Halo-Halo Bandung

Sumber:

ttps://www.google.co.id/partiturlaguhalo halobandung

\section{b. Fungsi dalam Pembelajaran Sejarah}

Peranan lagu 'Hallo-hallo Bandung' pada masa perjuangan menjadi terkenal bahkan menjadi bahasa sandi operasi serangan Tentara Republik Indonesia (TRI) terhadap pendudukan tentara sekutu dikenal dengan slogan 'Bandung rebut kembali', seperti syair yang diubah "Slagi hayat dan hasrat masih dikandung badan kita kan jumpa pula", agar lebih konteks dalam peristiwa Bandung lautan api tahun 1946, maka syair itu diubahnya menjadi "Sekarang telah menjadi lautan api mari bung rebut kembali".

Slogan semangat perjuangan rakyat Jawa Barat bersifat kedaerahan, kini menjadi populer dan menempatkan lagu ini menjadi bagian dari sejarah nasional dan lagu 'Hallo-hallo Bandung' berkumandang setiap tanggal 24 Maret mengiringi acara Longmars para pemuda dalam memperingati peristiwa Bandung Lautan Api. ${ }^{9}$

\section{Berkibarlah Benderaku \\ a. Lagu Berkibarlah Benderaku}

Bintang Sudibyo atau Ibu Sud (19081993) merupakan salah satu wanita nasionalisme pencipta lagu-lagu perjuangan 'Berkibarlah Benderaku' dikumandangkan setiap 17 Agustus dalam rangka HUT RI. lagu ini diciptakan berdasarkan kisah nyata masa revolusi Indonesia 1945, setelah menyaksikan pengalaman Yusup Rono Dipuro pelaku sejarah rekaman teks proklamsi adalah pimpinan RRI yang mempertahankan sang saka merah putih berkibar dihalaman kantornya, meskipun dalam ancaman senjata para kaum penjajah.

\footnotetext{
${ }^{9}$ Wisnu Mintargo. "Perjalanan Sejarah Lagu-lagu Perjuangan Indonesia dalam Konteks Persatuan Bangsa", dalam Jurnal Seni Pengetahuan dan Penciptaan Seni. Volume IX. No. 04-Juli, 2003. ISI Yogyakarta, hlm. 371.
} 


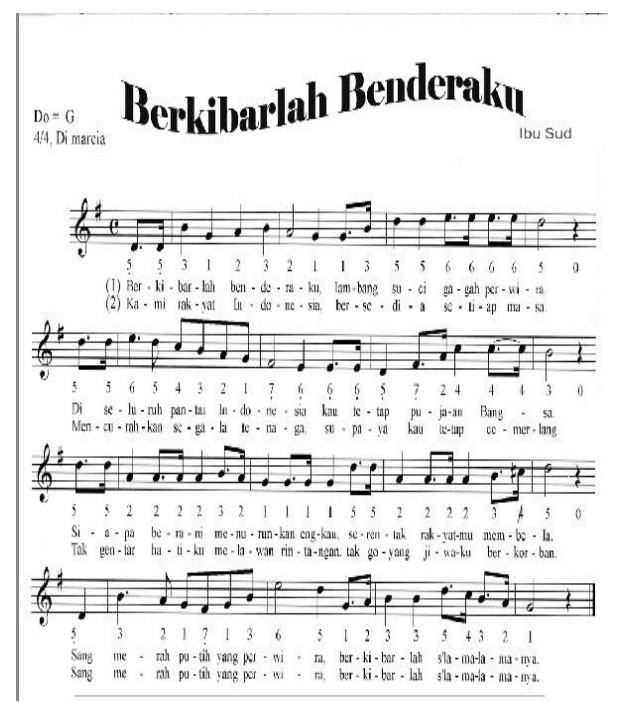

Gambar 4.6: Partitur Lagu Halo-Halo Bandung Sumber:

ttps://www.google.co.id/partiturlaguhalo halobandung

Atas jasa-jasanya dibidang musik tahun 2007 almarhumah Ibu Sud menerima anugerah penghargaan Bintang Budaya Paramadharma dari pemerintah RI. Selain itu Ibu Sud dikenal sebagai penyiar radio dan pencipta lagu anak-anak.

\section{b. Fungsi dalam Pembelajaran Sejarah}

Di bawah ancaman senjata Jusud Ronodipuro seorang pimpinan kantor RRI (Radio Republik Indonesia) ikut berjuang menjelang Agresi Militer Belanda I pada tahun 1947. Ia menolak untuk menurunkan Bendera Mereah Putih yang berkibar di kantor RRI, meski ada ancaman senjata api pasukan Belanda. Ancaman senjata dibalas Jusuf dengan gertakan, "Kalau memang bendera harus turun, maka dia akan turun bersama bangkai saya!". Inilah yang mengilhami lahirnya lagu "Berkibarlah Benderaku”.
Adapun fungsi lagu ini bagi pembelajaran sejarah ialah untuk membangkitkan semangat nasionalisme karena menghargai lambang negara yang pada masa penjajahan selalu terancam oleh para penjajah.

\section{Satu Nusa Satu Bangsa \\ a. Lagu Satu Nusa Satu Bangsa}

Liberty Manik

(1924-1993) merupakan pencipta lagu 'Satu Nusa Satu Bangsa' seorang pemain biola, penyanyi, penyiar radio RRI Yogyakarta, penulis buku dan jurnalis majalah Arena pimpinan Usmar Ismail 1946. Lagu ini diciptakan setelah menyaksikan semangat perjuangan rakyat mempertahakan kemerdekaan, sehingga lagu ini berisi anjuran persatuan dan kesatuan bangsa.

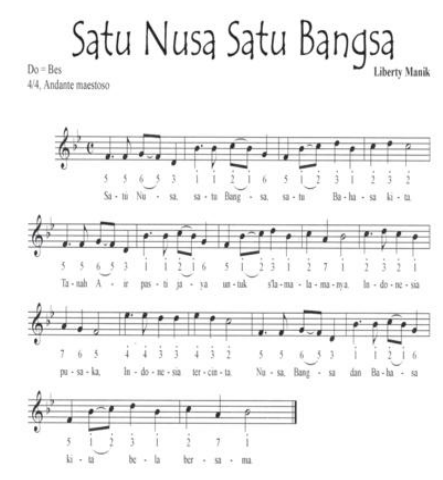

Gambar 4.7: Partitur Lagu Satu Nusa Satu Bangsa

Sumber:

https://www.google.co.id/satunusasatub angsa

\section{b. Fungsi dalam Pembelajaran Sejarah}

Lagu 'Satu Nusa Satu Bangsa' pertamakali diperdengarkan lewat siaran radio tahun 1947, ketika beliau bekerja di 
RRI Yogyakarta saat hangat-hangatnya agresi Belanda I. Atas jasa-jasanya dalam karya monumental dibidang musik tahun 2007 almarhum menerima penghargaan bintang Budaya Paramadharma dari pemerintah RI.

Lagu ini melambangkan bahwa sekalipun terancam akan bahaya bagi bangsa negara, sebagai warga negara Indonesia kita tidak dapat menghina lambang negara.

\section{Syukur}

\section{a. Lagu Syukur}

Husein Mutahar (1916-2004) pencipta lagu 'Syukur' meurpakan lagu himne puji syukur diciptakan dan dipersiapkan untuk menyambut kemerdekaan RI yang ketika itu diduganya hampir tercapai.

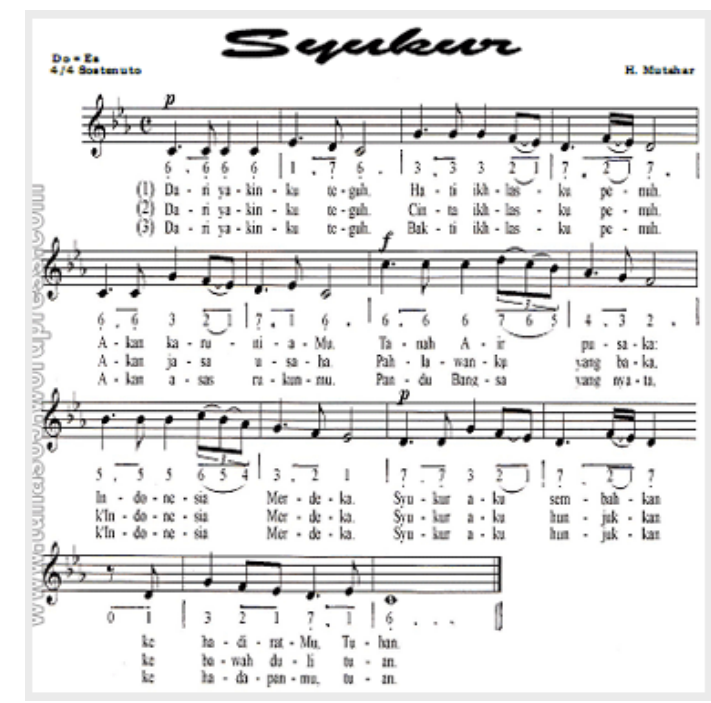

Gambar 4.8: Partitur Lagu Syukur

Sumber: ttps://www.google.co.id/syukur

\section{b. Fungsi dalam Pembelajaran Sejarah}

Lagu ini pertamakali dikumandangkan tahun 1946 di Istana Gedung Agung Yogyakarta. H. Mutahar tokoh utama pendiri gerakan Pramuka Indonesia, dan seorang perancang paskibraka pertama kali di Indonesia yang beranggotakan pelajar dari berbagai daerah. H. Mutahar adalah mayor Laut ABRI, memiliki tanda jasa Bintang Gerilya tahun 1948-1949 dan Bintang Maha putera menyelamatkan bendera Pusaka dari tangan pendudukan Belanda di Yogyakarta.

\section{Bangun Pemudi Pemuda \\ a. Lagu Bangun Pemudi Pemuda}

DR. HC. Alfred Simanjuntak (1920) merupakan pencipta lagu 'Bangun Pemudi Pemuda' berfungsi sebagai kontra propaganda Jepang wlaupun ia berprofesi sebagai guru hampir sepanjang hidupnya. saat menulis lagu ini di tahun 1943 ia bekerja sebagai guru sekolah rakyat sempurna Indonesia di Semarang, sebuah sekolah dengan dasar jiwa pratriotisme yang didirikan DR. Barder Djohan, Mr. Wongsonegoro dan Prada Harahap. 


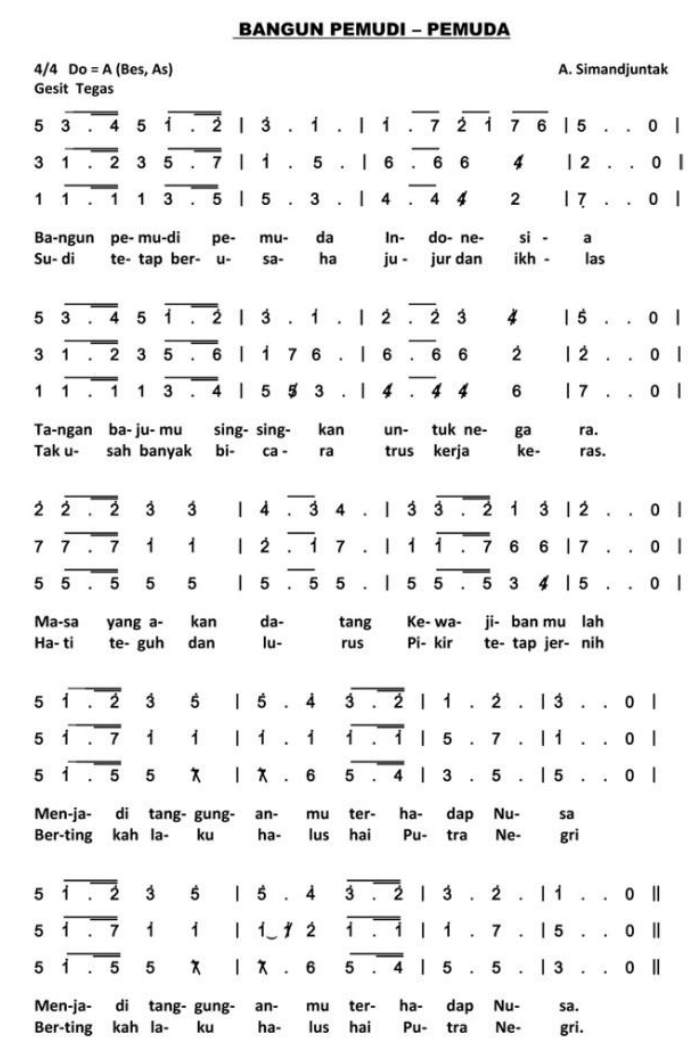

Gambar 4.9: Partitur Lagu Bangun Pemudi Pemuda Sumber:

ttps://www.google.co.id/bangunpemudip emuda

Lagu 'Bangun Pemudi Pemuda' digubahnya dalam suasana batin seorang anak yang gundah di negeri yang terjajah.

\section{b. Fungsi dalam Pembelajaran Sejarah}

Ide lagu ini diangkat ketika tahun 1945 rasa ingin merdeka kuat sekali bila bertemu kawan, pemuda saling berucap salam merdeka tutur Alfred Simanjuntak. Bahkan menurut pengakuannya, lagu tersebut nyaris mengancam jiwannya. Sebab gara-gara lagu yang dinilai patriotik itu, nama Alfred Simanjuntak masuk daftar orang yang dicari Kempetai Jepang untuk dihabisi karena lagunya dianggap kontra propaganda Jepang. Hingga saat ini lagu 'Bangun Pemudi Pemuda masih tetap dikumandangkan setiap perayaan Kemerdekaan 17 Agustus.

\section{Pentingnya Lagu-Lagu Perjuangan dalam}

Pembelajaran Sejarah untuk

\section{Membangkitkan}

Kesadaran

\section{Nasionalisme.}

Generasi muda merupakan penerus perjuangan bangsa, maka keberlangsungan suatu bangsa tergantung dari kualitas generasi mudanya. Karena itu setiap pemuda Indonesia, baik yang berstatus pelajar, pemuda, dan yang lain merupakan aktor-aktor yang diandalkan untuk mewujudkan cita-cita para founding leaders kita di masa yang akan datang. Para founding leaders telah meletakandasardasar dan tujuan kebangsaan, sebagaimana yang termaktub dalam pembukaan UUD 1945.

Di era globalisasi sekarang ini muncul permasalahan-permasalahan yang melanda bangsa Indonesia, seperti demoralisasi, lunturnya karakter bangsa, disintegrasi, konflik horizontal, KKN, anarkisme, budaya menerabas, dan lain-lain. Bahkan sekarang ini semangat kebangsaan, jiwa kepahlawanan, rela berkorban dan saling bergotong royong di kalangan masyarakat kira mulai menurun. Kita seperti telah kehilangan karakter yang 
selama berates-ratus tahun bahkan berabad-abad kita bangun. ${ }^{10}$

Melihat kenyataan ini diperlukan adanya semangat nasionalisme seperti halnya para pahlawan terdahuluyang dengan rela mengorbankan jiwa, raga dan hartanya untuk perjuangan bangsanya. Sikap rela berkorban tersebut sulit ditemukan pada jaman ini. Meskipun demikian karena permasalahan yang dihadapi berbeda antara dahulu dengan sekarang, maka sikap nasionalisme yang harus dimiliki generasi muda ialah bagaimana mereka mengisis kemerdkeaan ini dengan kegiatan-kegiatan yang positif yang berguna bagi dirinya,masyarakat dan untuk pembangunan bangsa Indonesia (Subaryana,2012).

Nasionalisme adalah masalah fundamental bagis sebuah negara, terlbihlebih jika negara tersebut memiliki karakter primordial yang sangat pluralistic. Anderson (1983) menggunakan istilah imajinasi untuk menggambarkan kemiripan makna tentang fantasi. Penjelasannya lebih condong menggunakan analisis sejarah politik untuk menjelaskan kaitan antara imajinasi kolektif yang mengikat suatu komunitas. Orang disatukan sebagai suatu negara karena persamaan identitas darah, ideologi dan kepentingan.

10 Azra, Azyumardi. Pendidikan Multikultural: Membangun Kembali Indonesia. Bhineka Tunggal Ika. 2002. Makalah Disampaikan dalam Symposium Internasional.
Sementara itu, Gellner (1997) melihat bahwa persatuan budaya sebagai hubungan antar manusia yang melandasi nasionalisme. Begitu juga dengan Ibn Khaldun dalam Nuseibeh (1969) menyatakan bahwa bahasa sebagai penegak anlunvia bagi tumbunya nasionalisme. Teori Renan tampaknya juga berpengaruh terhadap elit terpelajar Indonesia dalam membangitkan nasionalisme. Karena melalui kemauan bersama yang sangat diutamakan oleh kaum nasionalis Indonesia dalam rangka menghadapi kaum kolonialis.

Elit terpelajar ini dengan sengaja berupaya menciptakan mentalitas nasionalisme Indonesia. Hal ini sering diungkapkan oleh tokoh pergerakan, terutama Soekarno. Presiden pertama ini lewat pidato dan karya-karyanya selalu mengajak bangsa Indonesia utnuk menengok kejayaan ansga Indonesia di masa lampau (Sriwijaya dan Majapahit) dan bersatu padau untuk mengusir penjajah dari bumi Nusantara. Soekarno selalu mengutip ide Renan bahwa keberadaan suatu bangsa itu hanya mungkin apabila rakyat memiliki satu jiwa, karena rakyat Indonesia memiliki latar belakang sejarah yang sama dan untuk itu harus memiliki kemauan untuk bersatu, dengan tidak membeda-bedakan suku, ras dan agama.

Perubahan pandangan yang sangat signifikan terjadi pada awal abad ke-20, ketika bangsa Indonesia mulai menyadari eksistensinya di tenga-tengah bangsa lain, 
khususnya bangsa-bangsa di kawasan Asia. Salah satu faktor utama yang memicu bangkitnya kesadaran nasional Indonesia, pertama peninggalan nenek moyang dalam bentuk syair, epos dan narasi-narasi lain, peninggalan sejarah dalam bentuk monument, dokumen, lagu-lagu yang ada di piringan hitam dan institusi sosial lainnya yang kemudian dipicu oleh kemenangan Jepang atas Rusia (1905).

Ali (1963:291) menyebutkan tujuan pembelajaran sejarah nasional adalah: membangkitkan dan mengembangkan semangat kebangsaan; membangkitkan hasrat dalam mewujudkan cita-cita kebangsaan; menyadarkan siswa tentang cita-cita nasional dan perjuangan untuk mewujudkan cita-cita nasional tersebut sepanjang masa. Banks (1990: 282) menyatakan bahwa "Many educators and lawmakers believe that history should be thought in the public schools because it contributes to the development of patriotism and democratic attitude".

Sejalan dengan itu, Kochhar (2008:62) menjelaskan bahwa pembelajaran sejarah mengajarkan bagaimana memasukkan nilai-nilai nasionalisme ke dalam pikiran generasi muda, karena hanya melalui sejarah generasi muda memperoleh pengetahuan mengenai berbagai tindakan yang telah dilakukan oleh para patriot bangsanya. Wahid (2007) mengemukakan bahwa pembaharuan tekad bersama generas muda sangat memerlukan kesadaran sejarah perjuangan bangsa Indonesia di masa lalu. Oleh sebab itu generasi muda perlu mempelajari sejarah bangsanya secara utuh, objektif, dan kritis. Lembaran sejarah Indonesia memebrikan pelajaran yang sangat penting tentang bagaimana seharusnya generasi muda memainkan peran dan membuat lembaran sejarah pada saat ini dan masa yang akan datang.

Kartodirdjo (2005:122) menyatakan bahwa dalam rangka pembangunan bangsa, pembelajaran sejarah tidak semata-mata berfungsi untuk memberikan pengetahuan sejarah sebagai kumpulan fakta sejarah, tetapi menyadarkan siswa atau membangkitkan kesadaran sejarahnya. Untuk itu, lagu perjuangan sebagai sarana sangatlah efektif untuk menyadarkan diri setiap generasi terhadap sikap nasionalismenya. Untuk sampai pada sikap dan perilaku kesejarahan, terutama sikap nasionalisme diperlukan adanya kesadaran sejarah, sebagaimana diungkapkan oleh Soedjatmoko (1990: 67), bahwa kesadaraan sejarah akan membimbing manusia pada pengertian mengenal diri sendiri sebagai bangsa.

Berkaitan dengan hal tersebut Carr (1965:35) menyatakan bahwa "History is a continuous process of interaction between the historian and his facts, an unending dialog between the present and the past" ataus ejarah merupakan interaksi antara sejarawan dengan fakta-fakta sejarah dan 
dialog tanpa akhir antara masa sekarang dan masa lampau. Hasil penelitian yang dilakukan oleh Hoe (2007) dan Subaryana (2015) menyatakan bahwa pembelajaran sejarah memiliki pengaruh yang positif terhadap sikap nasionalisme.

Dari beberapa pendapat para ahli tersebut pembelajaran sejarah dapat membangkitkan semangat nasionalisme dengan berbagai cara salah satunya lewat menyanyikan lagu-lagu perjuangan di setiap kesempatan, bahkan dengan menggunakan ragam strategi pembelajaran yang dimiliki guru. Pembelajaran sejarah memiliki tugas utama untuk menanamkan semangat berbangsa dan bertanah air. Pembelajaran sejarah membangkitkan kesadaran empati pada siswa, yaitu sikap dan toleransi terhadap orang lain yang disertai kemampuan untuk imajinasi dan kreativitas. Kemampuan untuk mengidentifikasikan diri secara empatik dengan orang lain.

Tindakan seperti ini merupakan benang merah yang dapat membantu siswa mengenai kebersamaan dan solidaritas. Toleransi mengajarkan kepada siswa agar memiliki jiwa demokratis, menghargai dan menghormati orang lain, disertai dengan tanggung jawab dan komitmen dalam rangka mewujudkan cita-cita bangsa. Proses pengenalan diri sebagai titik awal timbulnya harga diri, kebersamaan dan keterikatan, dan sense of belonging yaitu rasa keterpautan dan rasa memiliki, serta sense of pride, yaitu rasa bangga terhadap bangsa dan tanah air (Wiriaatmadja, 2002: 156157). Hal ini seperti yang diungkapkan oleh Kartodirdjo (1999:21) bahwa dalam pengetahuan sejarah mengungkapkan heroism sepanjang sejarah yang penuh dengan role model kepemimpinan, kepahlawanan, etos perjuangan, serta penghayatan terhadap nilai-nilai luhur yang diwariskan oleh generasi terdahulu sangat berperan dalam usaha penanaman sikap nasionalisme bagi generasi muda.

Pada masa Revolusi Indonesia yaitu antara tahun 1945-1949 lagu-lagu diciptakan salah satunya berfungsi sebagai alat propaganda. Lagu Propaganda pada masa penduduka Jepang terdiri dari dua jenis lagu. Pertama, lagu-lagu jenis mars propaganda terbuka, dikenal sebagai lagu propaganda Asia Timur Raya, berjudu; 'Maju Putra-Putri Indonesia', Hancurkan Musuh Kita', dan 'Asia Sudah Bangun'. Lagu-lagu ini digunakan sebagai alat provokasi dan indoktrinasi semangat Jepang yang sengaja diciptakan pemerintah penguasa Dai Nippon guna mengajak bangsa Indonesia bersatu dengan Asia Timur Raya melawan Amerika dan sekutunya dalam Perang Dunia II.11

Kedua, lagu propaganda jenis mars yang bersifat terselubung, digunakan lagu 'Indonesia Raya', berfungsi sebagai alat penyamaran propaganda Jepang

\footnotetext{
11 Wisnu Mintargo. "Lagu Perjuangan Sebagai Media Propaganda”, dalam Jurnal Palanta Seni Budaya, No. 6, 2000
} 
membentuk negara kesatuan Asia Timur Raya, sebagai bujukan halus untuk menarik simpatik bangsa Indonesia. Lagu-lagu bersifat terselubung hasil kolaborasi pemerintah Jepang-Indonesia, misalnya lagu 'Menanam Jagung' ciptaan Bintang Sudibyo, menganjurkan masyarakat Indonesia bercocok tanam. Suatu saat lagu ini berfungsi mengatasi krisis kelaparan dan rakyat dianjurkan mendengarkan pidato Soekarno lewat intruksi radio propaganda Jepang Hosyo Kanri Kyoku. Saat inilah lagu itu diperdengarkan.

Pada saat rakyat Indonesia bersemangat mengatur keamanan dan menyelenggarakan pemerintahan, secara sepihak Perdana Menteri Jenderal Tojo Hideko melalui siaran radio Hosyo Kanri Kyoku di Jakarta, memberlakukan larangan mengumandangkan lagu kebangsaan 'Indonesia Raya' serta upacara pengibaran sang saka Merah Putih. Sebaliknya, pemerintah Jepang menetapkan UU No. 4 yang memberlakukan lagu 'Kimigayo' sebagai lagu kebangsaan Jepang, wajib diperdengarkan dan pengibaran bendera Himomaru wajib dilaksanakan.

Peranan lagu-lagu berbahasa Jepang yang selalu mendominasi acara siaran radio, disosialisasikan secara luas kepada masyarakat guna mengikis habis kebudayaan Barat di Indonesia, dengan mengganti lagu-lagu dari Jepang, seperti 'Sakura' dan 'Aikoku no Hana', sekaligus memberlakukan larangan mendengarkan lagu-lagu Barat.12

Lagu "Indonesia Raya" ciptaan W.R. Supratman, merupakan lagu kebangsaan bagi seluruh rakyat Indonesia, sebagai sebuah lagu yang dihormati dan dibanggakan, pembangkit semangat kebangsaan, dan terasa ada kesyahduan yang luar biasa dalam penjiwaannya.

Pada jaman penjajahan, pihak penjajah melarang rakyat menyanyikan lagu ini, tapi rakyat mengabaikannya, dan tetap menyanyikannya, sehingga bertambah jiwa nasionalisme, rasa kebangsaan, rasa senasib sepenanggungan, dan rasa seperjuangan, serta semakin memperkokoh persatuan dalam melawan penjajahan.

Berdasarkan ketetapan pemerintah tahun 1959, dimana lagu-lagu perjuangan bertujuan agar diajarkan dalam pendidikan nasional di seluruh tanah air serta diketahui oleh masyarakat Indonesia dengan berbagai kebhinekaannya guna membangkitkan semangat persatuan dan kesatuan Negara Republik Indonesia sebagai berikut.

1. Lagu-lagu perjuangan yang diciptakan oleh pencipta lagu Indonesia adalah ekspresi dari perasaan pejuang, melalui ungkapan suara rasa kebangsaan, nasionalisme dan persatuan yang dapat

\footnotetext{
${ }^{12}$ Winu Mintargo. "Fungsi Lagu-lagu Perjuangan Indonesia dalam Konteks Kemerdekaan Tahun 1945-1949”. 2001. Tesis untuk Magister Humaniora S-2. Program Pascasarjana Universitas Gajah Mada, Yogyakarta.
} 
dibagi menjadi tiga tyahap. Pertama, melodi diciptakan dengan sederhana agar mudah dinyanyikan oleh berbagai lapisan masyarakat Indonesia. Kedua, teks syair menggunakan bahsa Indonesia, agar dipahami oleh seluruh masyarakat Indonesia dengan berbagai kebhinekaannya. Ketiga, munculnya lagu-lagu perjuangan Indonesia adalah akibat adanya tekanan dari kaum penjajah pada masa perjuangan dan perang kemerdekaan di Indonesia.

2. Pada tahun 1960 Soekarno memerintahkan Husein Mutahar dan para pencipta lagu perjuangan Indonesia untuk menyelenggarakan upacara aubade pada hari besar nasional dengan memanfaatkan lagulagu perjuangan Indonesia sesuai dengan fungsinya. Untuk memaknai hasil perjuangan bangsa, maka lagu-lagu itu oleh pemerintah telah ditetapkan sebagai lagu nasional melalui surat keputusan Menteri Muda Pendidikan Pengajaran dan Kebudayaan No. 171 tanggal 17 Agustus 1959, yang diterbitkan oleh Balai Pustaka tahun 1963. Anjuran tersebut sampai saat ini tetap dilaksanakan oleh pemerintah, masyarakat serta dunia pendidikan guna dilestarikan, dan dipakai pada upacara kenegaraan puncak peringatan detik-detik proklamsi 17 Agustus 2002 di Istana Kepresidenan bersama iringan Korp Musik Markas Besar TNI Angkatan
Darat serta diakhiri dengan acara aubade lagu-lagu nasional bersama siswa-siswi SLTP se-DKI Jakarta bersama Orkes Simponi Sekolah Menengah Musik Negeri (SMM) Yogyakarta.

\section{Daftar Pustaka}

Arniati Prasedyawati Herkusumo. 1982. Chuo Sangiin Dewan Pertimbangan pada Pendudukan Jepang. Jakarta: Rosda Jayapura

Bakdi Soemanto. 1992. “Cornel Simanjuntak Seniman Pejuang dan Oejuang Seniman". Dalam Payaman J. Simanjuntak. (ed). Seniman Pejuang dan Pejuang Seniman. Jakarta: HIPSMI.

Binsar Sitompul. 1987. Cornel Simanjuntak, Komponis, Penyanyi dan Pejuang. Jakarta: Pustaka Jaya.

Garraghan, S.J., Gilbert J.A. 1957. Guide to Historical Method. New York: Fordham University of Chicago Press

H.B. Sutopo. 2006. Metodologi Penelitian Kulitatif. Surakarta: Universitas Sebelas Maret.

Kaelan, H., 2000. Pendidikan Pancasila. Yogyakarta: Paradigma

Kahin, George Mc Turman. 1985. Nasionalisme dan Revolusi di Indonesia. Jakarta: UNS dan Pustaka Sinar Harapan.

Kamajaya. 1979. Sejarah Bagimu Negri Lagu Nasional. Yogyakarta: U.P. Indonesia

Laura, dkk. 2014. 95 Strategi Pengajaran: Ide-Ide Remodeling Pelajaran yang Mengacu ke Kurikulum Inti 
(terjemahan). Jakarta: Indeks Permata Puri Media

Mack, Dieter. 1995. Sejarah Musik Jilid 4. Yogyakarta: Pusat Musik Liturgi

Merrill,dkk. 2012. Pembelajaran Aktif yang Menginspirasi; Buku Pegangan Lengkap untuk Guru Masa Kini (terjemahan). Jakarta: Indeks Permata Puri Media

Miftahul Huda. 2013. Model-Model Pengajaran dan Pembelajaran: Isu-Isu Metodis dan Paradigmatis. Yogyakarta: Pustaka Pelajar

P3MP-LPM. 2012. Pedoman Model Pembelajaran Berbasis Pedagogi Ignasian. Yogysakarta:USD.

Pardosi Siagian. 1975. Indonesia yang Kucinta, Penyebar Musik Indonesia. Yogyakarta.

Paul Ginis. 2008. Trik \& Taktik Mengajar: Strategi Meningkatkan Pencapaian Pengajaran di Kelas. Jakarta: Indeks

Ramadhani Masykur. 2011. Penerapan Metode Pembelajaran Talking Stick Untuk Meningkatkan Prestasi Belajar Siswa Pada Pokok Bahasan Koloid Di Kelas Xi Ipa Sma Negeri 7 Pekanbaru. Universitas Riau

Rolland, Romain, ed. 1962 The International Library of Music for Home and Music Literatur 2, New York: University Society

S.Adisusilo, 2012. Pembelajaran NilaiKarakter. Kostruktivisme dan VCT sebagai Inovasi Pendekatan Pembelajaran Afektif. Jakarta:PT.RajaGrafindo Persada

Sartono Kartodirdjo. 1992. Pendekatan Ilmu Sosial Dalam Metodologi Sejarah. Yogyakarta: Ombak

Sartono Kartodirdjo. 1999. Pengantar Sejarah Indonesia Baru: Sjearah Pergerakan Nasional. Penerbit PT Gramedia Pustaka Utama, Jakarta.

Soedarsono. 1998. Seni Pertunjukkan di Era Globalisasi. Jakarta: Departemen Pendidikan dan Kebudayaan

Sutrisno Kutojo dan Mardanas Safwan. 1978. Pahlawan Nasional W.R. Supratman. Jakarta: Mutiara.

Sri Martono. 1953. Kehidupan Seni Suara Tahun 1945 - 1952. Yogyakarta: Kementerian Penerangan Republik Indonesia.

Wina Sanjaya. 2006. Strategi Pembelajaran. Jakarta, Prenada Media Group

Wisnu Mintargo. "Lagu Perjuangan Sebagai Media Propaganda", dalam Jurnal Palanta Seni Budaya, No. 6, 2000

2001. "Lagu Perjuangan Indonesia sebagai Media Propaganda". Dalam Jurnal Pelanta Seni Budaya. Maret, no.6. ASKI Padangpanjang.

Perjuangan Indonesia dalam Konteks Kemerdekaan Tahun 1945-1949". Tesis untuk Magister Humaniora S-2. Program Pascasarjana Universitas Gajah Mada, Yogyakarta.

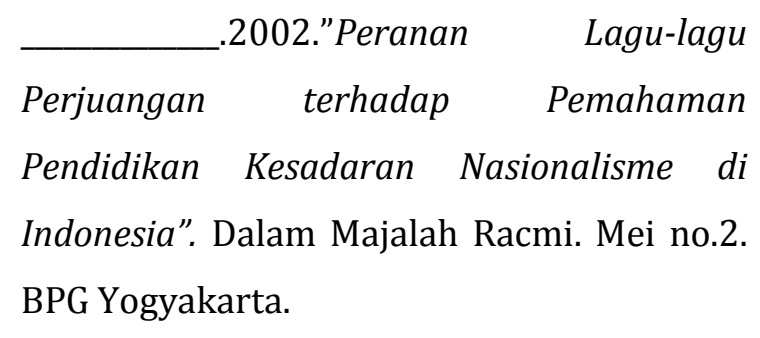
.2002."Peranan Lagu-lagu

(1)

.

